\title{
Divine, Philosophical, and Existential dimension of Gerard Manley Hopkins' poetry
}

\author{
Anil Jyadeo Ganvir
}

Assistant Professor and Head, Department of English, Shree Pandharinath Arts and Commerce College, Narkhed, Dist. Nagpur, India

\begin{abstract}
The research paper aims to exhibit and explore pious, philosophical, and existential aspects of Gerard Manley Hopkins' selected poems which remain an invaluable contribution to the shape and development of the Christian thought both for theologians and academic critics. The author of the article emphasizes that Hopkins's challenging, highly ambitious and complex works, filled with spiritual anxiety, dualism and struggle between reason and sensuality, harmony and violence, happiness, and suffering, were mostly reject able by the Victorian audience and critics. Hopkins's "model of the world" (Barańczak 1981), his depiction of tragic human existence and the presentation of two contradictory facets of God meet more the expectations of contemporary readers and are more appreciable by today's thinkers, philosophers, and critics.
\end{abstract}

Keywords-Hopkins, Christianity, philosophy, existentialism, Victorians.

\section{INTRODUCTION}

Throughout the century, faith, religion, and spirituality have become crucial subjects in various scientific and artistic works, being the inspiration for theologians, philosophers, artists, writers, playwrights, and poets. Irrespective of time, place, social, political conditions and cultural differences and boundaries artists have invariably endeavoured to explore the nature of God and to improve their knowledge on the mystery of the universe and the existence of man. In Christian literary tradition, especially in Catholic writings, God, man, and man's relationship with God constitute dominant themes which are frequently expressed by unique, innovative language. The fact is that in the Western literary and artistic world, particularly in the era of religious decline, progressive secularization and debasement of moral and ethical values Christian writers significantly contribute to the promulgation of faith and ecclesiastical spirit amid their reading public. In Anglo-Saxon literary tradition, it is undoubtedly Catholic writers, particularly $18^{\text {th }}$ and $19^{\text {th }}$ century poets, such as Alexander Pope and Gerard Manley Hopkins. They, constituting the minority in Anglican society and non-Catholic circles, excelled at expressing their religious ardour and spiritualism. Both the former and the latter, although their flair and aptitude, were regard able as controversial, too zealous and, consequently, became overshadowed by their contemporaries.

\section{THE PECULIARITY OF HOPKINS}

Because of the linguistic and stylistic complexity of the poems as well as the mysterious arcane of the individual life, Gerard Manley Hopkins (1844-1889) deserves special attention, both as poet and priest. When mentioning to the poet's life and literary output, one might label them like a vein of anguish, religious zeal, spiritual disharmony, and opposition. Numerous critics designate him anti-democrat, being both revolutionary and reactionary, remarkably individual, and eccentric in his poetry and life (Armstrong 1993). Born and bred in the tradition of the High Anglican Church in the mid-Victorian period, Hopkins converted to Catholicism, has questioned the authenticity of the English Church during his studying at Oxford University. This period followed the publication of Newman's Apologia pro-Vita Sua (1864) (MacKenzie 1993). Hopkins, who was dithering between his Anglican roots, particularly the ceremonial peripheral of the High Anglican Church he and his family signified and his future calling as a Jesuit priest, created poetry full of fierce Catholic piety but simultaneously sensual violence. The English poet viewed belief as a basis of inspiration and artistic fulfilment yet mingled with fear and internal labyrinth. Thus, it originates as no surprise that he was regardable as the most controversial figure among Victorian poets who established unfavourable reviews from literary critics and dispiriting responses from the audience. 
Individual Experience: In everything, Hopkins underscored the individuality of experience and exceptionality of the transitory aspect of everyday experience. His religious beliefs were modellable on their philosophy of Duns Scotus (1265/66 -1308), a mediaeval Franciscan, the writer of the doctrine of Scepticism, whom he deeply admired, from whom he borrowed the concept of haecceity or "thisness" and the formula of individualism and introspective attitude, and to whom he devoted his poem "Duns Scotus's Oxford" (1972). Scotus contributed to Hopkins' influencing and developing both the religious and artistic facet of his output as well as he compelled the English poet considers profoundly for the moment of vision, of interior perception into an object is being, as conflicting to the perfunctory, confused knowledge with which the widely held of people are satisfied (MacKenzie 1993). Furthermore, the English poet derived inspiration from $17^{\text {th }}$ century metaphysical poets, George Herbert. Similarly, to Herbert, Hopkins displayed the penetrating struggles of a profoundly religious man who had doubts, hesitations and felt forsaken by God, endeavouring to release himself from bonds and yet realizing that he is unable of renouncing God's protection (Sikorska 2007).

Hopkins' poems such as "The Wreck of the Deutschland", commemorating the five Franciscan nuns, exiled by the Falk Laws drowned between midnight and morning of Dec. $\left.7^{\text {th }}, 1875\right)$, "God's Grandeur, and "The Starlight Night", "Pied Beauty", "Duns Scotus's Oxford" and "Spring and Fall", complex, demanding, and highly problematic, is appealing more to contemporary readers than to the $19^{\text {th }}$-century public, being accustomed mainly to didactic. As it was mentionable previously, Hopkins is a profoundly religious poet, remained under the significant impact of Metaphysical poetry, occupied with religiousness, mannerism, philosophy and which had rudiments of sensory violence and passion of emotional state. Using all these features and constituents, the poet paid homage to God and strived to understand his magnitude and to discover the mystery of creation, nature, and its association with man.

\section{REFLECTION OF SUBJECT MATTER AND LINGUISTIC PATTERN}

Dichotomy besides paradox establish the essence of his poetry, and they are reflectable in every subject-matter and linguistic pattern. God, a central figure of his almost every poem, is depictable, as a creator, lifegiver, and feeder, but, as a severe final judge who reprimands, punishes, and takes a human life. The directly above quotations exemplify these antagonisms:
Thou mastering me

God! Giver of breath and

bread;

World's strand, sway of the

sea;

Lord of living and dead;

Thou hast bound bones and

veins in me,

fastened me flesh,

Moreover, after it almost

unmade, what with dread,

thy doing: and dost thou

touch me afresh?

Over again, I feel thy finger and find thee.

(quoted in Barańczak, 198, p.

Be adorned among men,

God, three-numbered

form;

Wring thy rebel, dogged in

den,

Man's malice, with

wrecking and storm.

Beyond saying sweet, past

telling of tongue,

Thou art lightning and

love, I found it, a winter and warm;

Father and fondler of

heart thou hast wrung;

Hast thy dark descending

and most art merciful then.

(ibid, p. 30)

In the first piece of the poem, one can see two facets of the Lord - a peaceful, life-providing versus fiery, Spartan and life-taking, thus far they cannot be classifiable as merely positive and negative. In Hopkins' writing, God is always preferable to as the omnipotent, superb spiritual phenomenon and even though he occasionally severely punishes people, he is still unique to be admirable and 
praised, which develops visible in the second excerpt of the poem.

Dualism unites these two fragments of "The Wreck of the Deutschland" as well as other works of the English poet, and opposition in presenting a central theme as well as linguistic and stylistic complexity. On the one hand, the poet portrays God as well as nature and man, created in his image, and their relationship, in a highly emotional ecstatic, all the more violent technique to reveal not only his spiritual enthusiasm and steadfast belief but then again also to validate how difficult, painful and even distressing the act of faith and the process of searching for God can be. Hopkins intensifies such a complex perception of Divinity and defiance to life via his complex language and style, primarily through his intricate metrical system called sprung rhythm which relies on a tangled use of accentuated feet and non-accentuated syllables. Only appreciations to such discordant, irregular rhythm, being his creation, the artist might methodically show the internal chaos of a Christian. This distrustful and melancholy vision of life and Christian anguish is visible in his "Dark Sonnets" inscribed between 1885 and 1886, the most conspicuous instance of which is the mentioned earlier "The Wreck of the Deutschland". Inscribed at the end of the author's life, perhaps best illustrate a human soul who is desperately searching for Christ and then for the divine elegance that appears to have disappeared from the world (Stephen 1986). Conversely, one may notice a harmonious, composed, and reflective accent in his poems which appears to the artist's quietening down and his acceptance of the situation:

Patience, hard thing! The hard thing to pray,

However, kid for, patience is! Patience who asks

Wants war, wants wounds weary

his times, his tasks;

To do without, take tosses , and obey.

And where is he who more and more distills

Delicious kindness? - he is patient. Patience fills

His crisp combs and that comes to those ways we know.

(ibid 108)
As was pointe able out before, Gerard Manley Hopkins used nature as one of his central themes, and he always described it concerning God. Hopkins puts forward the belief that nature, shaped in Lord's image, is the language God speaks. According to him every creature which is the portion of the earth has an exclusive quality or vital

"whatness" called as inscape, the individual 'distinctive' form, the 'oneness' of a natural object, which is put into action thanks to instress, the divine energy that both upholds the inscape of all things, determines it and makes it alive to the senses of the observer. In his poetry instress, which is a mystifying illumination or insight into the underlying order and unity of creation (Cuddon 91) is customizable by

God. In Hopkins' most famous works demonstrating his devotional poetry, such as "Pied Beauty", "God's Grandeur" otherwise "The Windhover: to Christ our Lord" the poet prays to God's act of creation and describes nature in terms of Christ-like qualities:

I caught this morning morning's minion,

the kingdom of daylight's

dauphin, dapple-dawn-drawn Falcon, in his riding

Of the rolling level underneath him

steady air, and striding

High there, how he rang upon the rein of a wimpling wing

In his ecstasy! Then off, off forth on

swing,

As a skate's heel sweeps smooth on a bow-bend: the hurl a gliding

Rebuffed the big wind. My heart in

hiding

Stirred for a bird - to achieve of, the mastery of the thing!

Brute beauty and valour and act, oh, air, pride, plume, here

Buckle! Moreover, the fire that breaks from thee then, a billion

Times told lovelier, more dangerous, $O$ my chevalier!

(ibid 66)

Likewise, to "Pied Beauty" as well as "God's Grandeur", that Hopkins measured being his best work, reflects a 
harmonious, serene, highly spiritual and sensory side of Hopkins' output. In "The Windhover" (1877), the artist created an image of admiration of the energetic and gorgeous Falcon, constitutes the thought of a poet on different rudiments of the individuality and unity of God. However, Hopkins often presented two contradictory facets of nature. As soon as set beside the afore-mentioned serene, peaceful, and graceful features of God's original act, nature is too the source of destruction and agony. Unlike in "The Windhover" or in

"Hurrying in harvest" (written between 18761889) anywhere the landscape appears to express the voice of God besides wherever its mysticism becomes virtually Eucharistic (in the author's words), in "The Caged Skylark" (written between 1876-1889) Hopkins obtainable the image of a bird that should be set free but is bound in prison and, in a figurative sense, he likens the eponymous caged skylark to the imprisoned human soul. A damaging and deteriorating aspect of nature and humanity is perhaps most brightly portrayed within "I Wake and Feel the Fell of Dark, not Day" (1885), or else "No worst", that are Hopkins' crisis sonnets full of feelings of resentment, trepidation and disgust with his physical nature. The two edges of nature and the existence of a human being, a peaceful and affable, and a violent, distressing, then again, are mergeable. For example, in "The Caged Skylark" the image of a bird in captivity which exemplifies the confined human soul implicitly carries the conviction that man's spirit, although "flesh-bound", finally frees itself (Sikorska 2007). In similar vein "That nature is a Heraclitan Fire and of the comfort of the Resurrection" covers both the elements of dread, bedlam, and ferocity on the one hand and consolation and solace on the other hand. As the title suggests, the Resurrection of Jesus Christ puts an end to the earthly suffering and brings comfort to human souls: "Enough! The Resurrection, a heart's-clarion! Away grief is gasping, joyless days, dejection" (quoted in Barańczak, p. 114).

\section{CONCLUSION}

To sum up, it is possible to argue that, given the circumstances, the spiritual, philosophical, and existential dimension of Gerard Manley Hopkins' poetry remains an invaluable influence on the shape and development of the Christian thought both for theologians and academic critics. These problematic, highly ambitious and ambiguous works, filled with spiritual anxiety, dualism and struggle between reason and sensuality, harmony and violence, the Victorian audience and critics mostly rejected happiness and suffering. Hopkins' "model of the world” (Barańczak 1981), his depiction of the tragedy of human existence and the presentation of two contradictory facets of God seemingly meet more the expectations of contemporary readers, more appreciated by today's thinkers, philosophers, and men of letters.

\section{REFERENCES}

[1] Armstrong I. (1993), Victorian Poetry. Poetry, Poetics and Politics, London, and New York: Routledge.

[2] Barańczak S. (ed.) (1981), Gerard Manley Hopkins, Kraków: Znak.

[3] Cuddon J. A. (ed.) (1991), A Dictionary of Literary Terms and Literary Theory, Oxford, Cambridge: Blackwell Reference.

[4] MacKenzie N. H. (1993), Hopkins, In Pollard A. (ed.), The Penguin History of Literature. The Victorians, (pp. 413-433), Longman: Penguin Books.

[5] Sikorska L. (2007), A Short History of English Literature, Poznan: Wydawnictwo Posnanski.

[6] Stephen M. (1986), English Literature. A Student Guide, London, and New York: Longman. 